\title{
TWO NEW SPECIES OF TREMATODES OF THE GENUS PARAMETORCHIS FROM FUR-BEARING ANIMALS
}

\author{
By Emmett W. Price
}

Of the Zoological Division, Bureau of Animal Indusiry, United States Department of Agriculture

In this paper two trematodes which appear to be new species are described. These fiukes belong to the family Opisthorchiidae Braun, 1901, and to the genus Parametorchis Skrjabin, 1913. The first of these species was forwarded to the Bureau of Animal Industry, October 13, 1927, by Dr. J. E. Shillinger, of the Bureau of Biological Survey, who collected them from the gall bladder of a silver fox from Wisconsin. For this species the name Parametorchis intermedius is proposed. The second species, comprising about a dozen specimens, was collected from the gall bladder of a mink by Dr. Ronald G. Law, of the Experimental Fur Farm, Kirkfield, Ontario, and forwarded to the Bureau of Animal Industry for identification on February 2, 1929. For this species the name Parametorchis canadensis is proposed.

The genus to which these species obviously belong was proposed by Skrjabin (1913) and is characterized as follows:

\section{Genus PARAMETORCHIS Skrjabin, 1913}

Generic diagnosis.-Flattened, moderate-sized distomes, attenuated anteriorly and rounded posteriorly. Cuticle spiny. Suckers equal in size and weakly developed; acetabulum at the border of the first and second fourth of body length. Pharynx and a smaller esophagus present. Intestinal ceca extend to posterior end of body. Testes lobed and arranged tandem in posterior half of body. Uterus rosette-shaped, in anterior half of body, surrounding the acetabulum. Vitellaria lateral of uterus, in anterior half of body, and uniting in front of uterus. Ovary lobed, cephalad of testes. Receptaculum seminis moderately large, lateral of ovary. Parasites of the gall bladder of mammals.

Type species.-Parametorchis complems (Stiles and Hassall, 1894).

No. 2809.-Proceedings U.S. National Museum, Vol. 76, Art. 12 
Specific diagnosis.-Parametorchis: Body linguiform, the anterior end attenuated and posterior end rounded, 3 to $3.5 \mathrm{~mm}$. long by $1 \mathrm{~mm}$. wide in the region of the anterior testis. Oral sucker terminal, $155 \mu$ to $262 \mu$ long by $232 \mu$ to $278 \mu$ wide, weakly muscular. Prepharynx absent; pharynx strongly muscular, $170 \mu$ to $186 \mu$ long by $140 \mu$ wide. Esophagus very short; intestinal ceca wide and sinuous, terminating $77 \mu$ to $124 \mu$ from the posterior end of body. Acetabulum weakly developed, slightly oval transversely, $150 \mu$ long by $200 \mu$ wide, and situated about $775 \mu$ to $997 \mu$ from the anterior end. Testes deeply lobed, tandem or slightly oblique, and situated in the posterior half of body. The anterior testis is from $262 \mu$ to $310 \mu$ long by $325 \mu$ to $496 \mu$ wide and the posterior from $310 \mu$ to $500 \mu$ long by $387 \mu$ to $496 \mu$ wide. Cirrus pouch absent. Seminal vesicle slender and sinuous, and usually obscured by the convolutions of the uterus. Ovary trilobed, $108 \mu$ to $140 \mu$ long by $200 \mu$ to $260 \mu$ wide, and situated a short distance in front

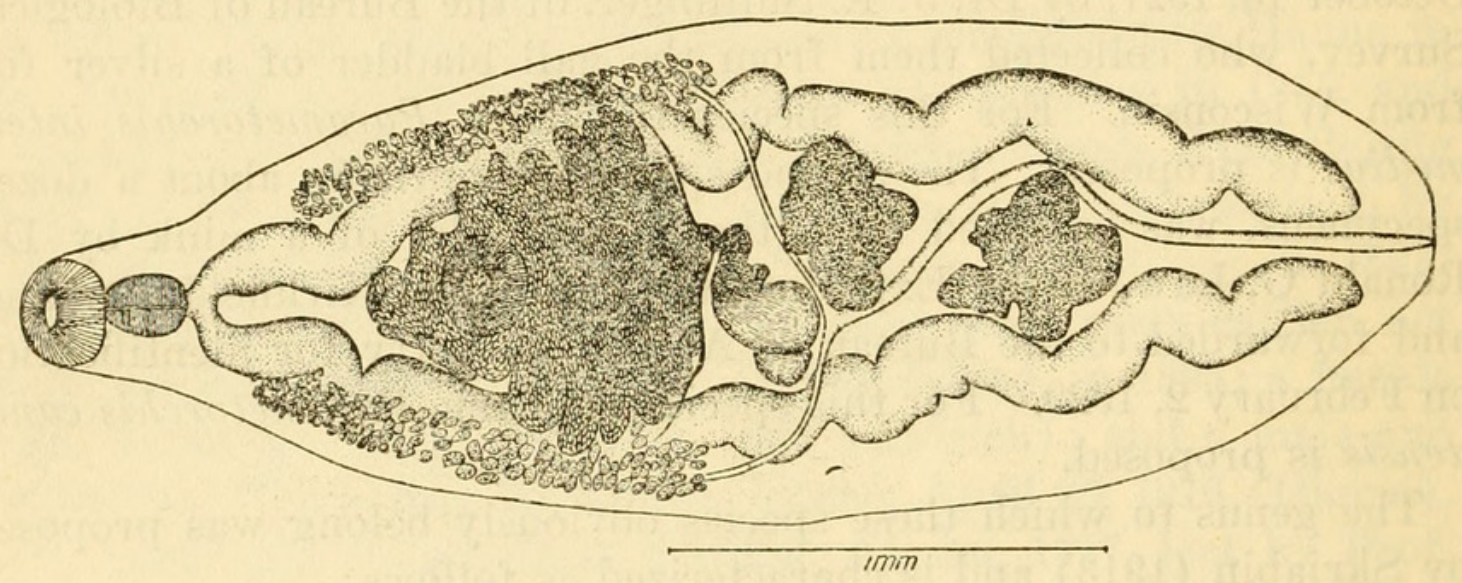

F'igure 1.-Parametorchis intermedus, new spectes. Ventral view

of the anterior testis. Receptaculum seminis elongated and slightly twisted, and situated to the right and caudad of the ovary. Vitellaria lateral, extending from slightly behind the level of the esophageal bifurcation to the level of the anterior border of the ovary. Uterus composed of close transverse coils and extending from ovary to a short distance in front of acetabulum. Genital pore median, about $850 \mu$ from the anterior end of body. Excretory canal sigmoid, branching at the level of the anterior border of the anterior testis, the two branches extending extracecally to about the level of the pharynx; excretory pore terminal. Eggs oval, $30 \mu$ long by $15 \mu$ wide, and yellowish brown in color.

Host.-Silver fox (Vulpes fulva.)

Location.-Gall bladder.

Distribution.-United States (Wisconsin.)

Type specimens.-United States National Museum Helminthological Collection No. 27857; paratypes No. 28179. 
This species apparently occupies a position intermediate between Parcmetorchis complexus, which was described by Stiles and Hassall (1894), from the gall bladder of cats from New York, Maryland, and District of Columbia, and $P$. noveboracensis which was described by Hung (1926) from the gall bladder of a cat from New York. In the former species the testes are deeply lobed and the vitellaria unite in the median line forming a $U$ around the uterus; in the latter species the testes are almost round, the posterior being only slightly indented, and the vitellaria do not unite in front of the uterus. The peculiar character of the vitellaria in $P$. complexus appears to be constant and not changed by host relationship. Specimens of this species which the writer has examined (U. S. N. M No. 14407), collected January 21, 1907, by E. C. Stevenson from a blue fox which died in the National Zoological Park, Washington, D. C., conform in this respect to the type specimens from the cat. $P$. intermedius is considerably smaller than either $P$. complexus or $P$. noveboracensis.

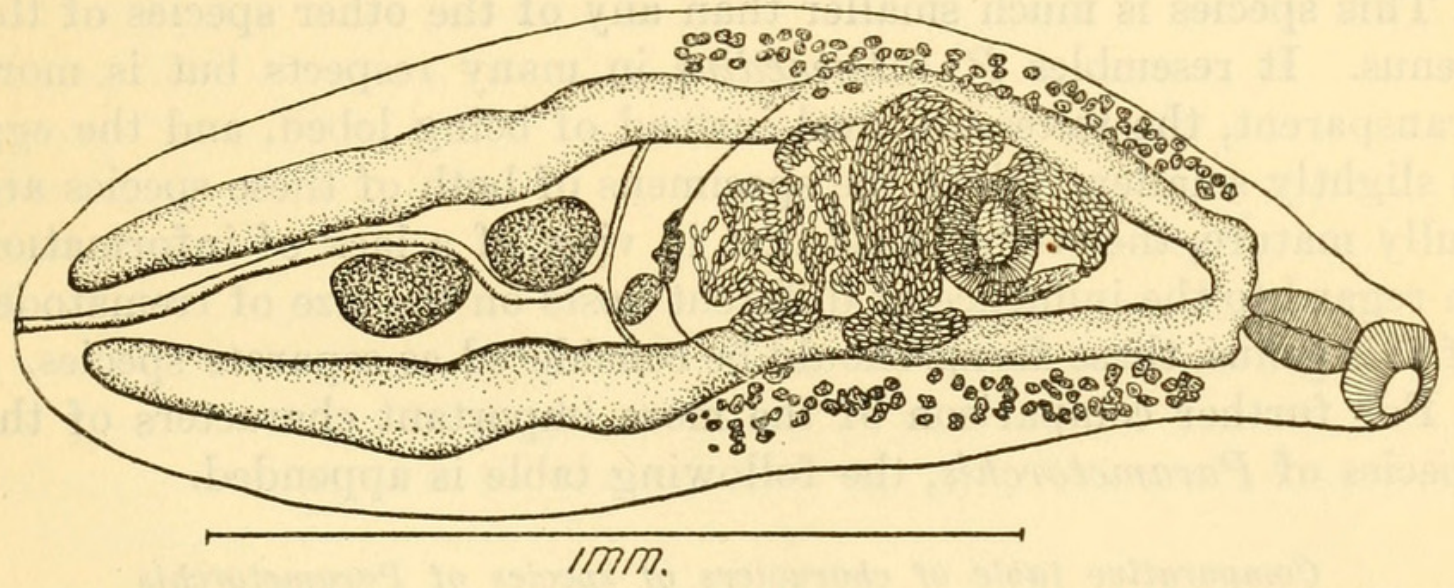

Figure 2.-Parametorchis canadensis, new species. Dorsal vlew

The body form and shape of the testes are similar to the former species, but the arrangement of the vitellaria is similar to that in the latter species. On the basis of these differences, the writer ferls justified in considering $P$. intermedius a distinct species.

PARAMETORCHIS CANADENSIS, new species

Specific diagnosis.-Parametorchis: Body linguiform, transparent, 1.7 to $2 \mathrm{~mm}$. long $590 \mu$ to $687 \mu$ wide in the region of the anterior testis. Cuticle missing owing to the somewhat macerated condition of the specimens. Oral sucker terminal, $93 \mu$ to $108 \mu$ long by $140 u$ to $155 u$ wide. Prepharynx absent; pharynx muscular, $108 \mu$ to $140 \mu$ long by $62 \mu$ to $93 \mu$ wide. Esophagus very short; intestinal ceca slightly sinuous, terminating $70 \mu$ to $90 \mu$ from the posterior end of the body. Acetabulum $125 \mu$ long by $140 \mu$ wide, weakly muscular, and situated about $470 \mu$ from the anterior end. Testes oval or slightly indented, and situated tandem in the posterior half of body; they are about equal 
in size, $186 \mu$ long by $125 \mu$ wide. Cirrus pouch absent. Seminal vesicle slender and sinuous, its posterior end lying on a level with the center of the acetabulum. Ovary trilobed, small, and situated about twice its own length in front of the bifurcation of the excretory vesicle. Receptaculum seminis large and pyriform, and situated to the right and caudad of the ovary. Vitellaria lateral, extending from a short distance caudad of the esophagus bifurcation to the level of the ovary. Uterus composed of close transverse coils which are filled with small eggs. The genital pore is situated $400 \mu$ to $600 \mu$ from the anterior end of body. Excretory system similar to that in other species of the genus. Eggs oval, $22 \mu$ long by $11 \mu$ wide, and yellowish brown in color.

Host.-Mink (Mustela vison).

Location.-Gall bladder.

Distribution.-Canada (Kirkfield, Ontario).

Type specimens.-United States National Museum Helminthological Collection No. 28180 ; paratypes No. 28366.

This species is much smaller than any of the other species of the genus. It resembles $P$. intermedius in many respects but is more transparent, the testes are oval instead of being lobed, and the egg is slightly smaller. Since the specimens of both of these species are fully mature, the writer feels that in view of a lack of information in regard to the influence of different hosts on the size of trematodes of this genus, these forms should be considered as separate species.

For further comparison of the more important characters of the species of Parametorchis, the following table is appended.

Comparative table of characters of species of Parametorchis

\begin{tabular}{|c|c|c|c|c|}
\hline & $\begin{array}{l}\text { Parametorchis } \\
\text { complexus }\end{array}$ & $\begin{array}{l}\text { Parametorchis } \\
\text { noveboracensis }\end{array}$ & $\begin{array}{c}\text { Parametorchis } \\
\text { intermedius }\end{array}$ & $\begin{array}{l}\text { Parametorchis } \\
\text { canadensis }\end{array}$ \\
\hline $\begin{array}{l}\text { Body form } \\
\text { Size: } \\
\quad \text { Length } \\
\quad \text { Width } \\
\text { Oral sucker... } \\
\text { Acetabulum } \\
\text { Pharynx } \\
\text { Ovary } \\
\text { Intestinaì ceca. } \\
\text { Testes.... }\end{array}$ & 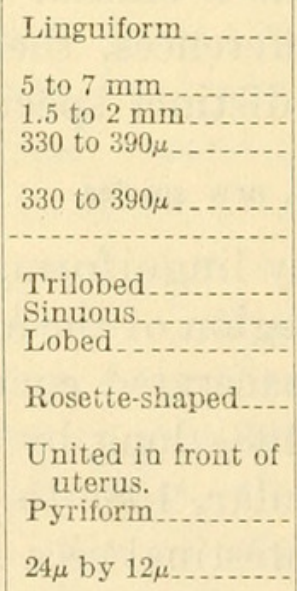 & $\begin{array}{l}\text { Linguiform } \\
6 \text { to } 6.3 \mathrm{~mm} \\
2.2 \text { to } 2.6 \mathrm{~mm} \\
232 \text { to } 242 \mu \\
232 \text { to } 242 \mu \text { by } 281 \text { to } \\
300 \mu \text {. } \\
\text { Trilobed } \\
\text { Almost straight } \\
\text { Almost round...... } \\
\text { Rosette-shaped.... } \\
\text { Not united..... } \\
\text { Pyriform } \\
28-32 \mu \text { by } 15-18 \mu\end{array}$ & $\begin{array}{l}\text { Linguiform } \\
3 \text { to } 3.5 \mathrm{~mm} \\
1 \mathrm{~mm} . \\
155 \text { to } 262 \mu \text { by } 232 \text { to } \\
278 \mu \text {. } \\
150 \mu \text { by } 200 \mu \\
170 \text { to } 186 \mu \text { by } 140 \mu \\
\text { Trilobed. } \\
\text { Sinuous. } \\
\text { Lobed } \\
\text { Compact transverse } \\
\text { coils. } \\
\text { Not united } \\
\text { Slightly twisted........ } \\
30 \mu \text { by } 15 \mu\end{array}$ & $\begin{array}{l}\text { Linguiform. } \\
1.7 \text { to } 2 \mathrm{~mm} \text {. } \\
590 \text { to } 687 \mu \text {. } \\
93 \text { to } 108 \mu \text { by } 140 \\
155 \mu \text {. } \\
125 \mu \text { by } 140 \mu \text {. } \\
108 \text { to } 140 \mu \text { by } 62 \text { to } \\
93 \mu \text {. } \\
\text { Trilobed. } \\
\text { Slightly sinuous. } \\
\text { Oval or slightly } \\
\text { lobed. } \\
\text { Compact trans } \\
\text { verse coils. } \\
\text { Not united. } \\
\text { Pyriform. } \\
22 \mu \text { by } 11 \mu .\end{array}$ \\
\hline
\end{tabular}




\section{REFERENCES}

Hung, See-Lü.

1926. A new species of fluke, Parametorchis noveboracensis, from the cat in the United States, Proc. U. S. Nat. Mus., Wash. (2627), vol. 69 , art. 1 , pp. $1-2$, fig. 1 .

SkRJABIN, K. I.

1913. Vogeltrematoden aus Russich Turkestan, Zool. Jahrb., Jena., Abt. f. Syst., vol. 35, pp. 351-388, pls. 13-14, figs. 1-16.

Stiles, Ch. Wardell; and Hassall, albert.

1894. A new species of fluke (Distoma [Dicrocoelium] complexum) found in cats in the United States, with bibliographies and diagnoses of allied forms. (Notes on parasites, 21.) Vet. Mag., Phila., vol. 1, June, pp. 413-432, pls. 1-4, figs. 1-19. [MS. dated March 2, 1893.] 

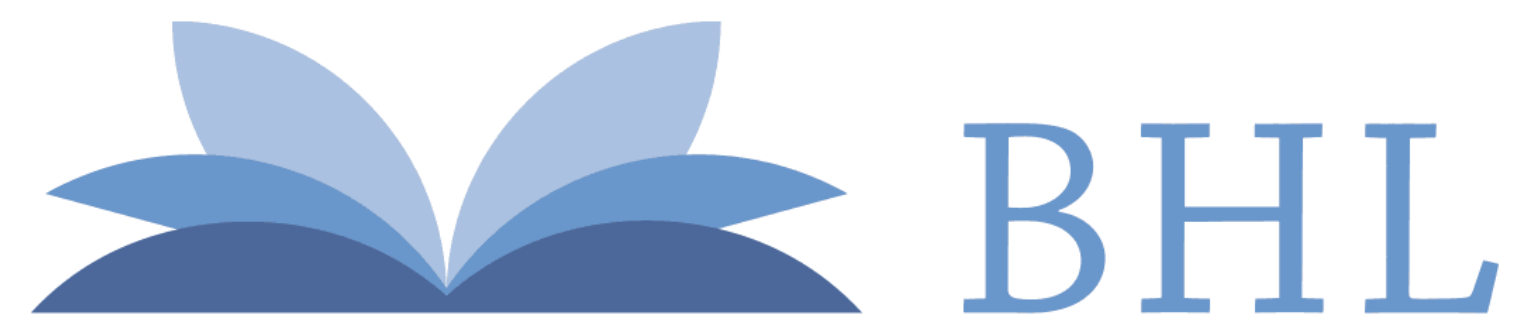

\section{Biodiversity Heritage Library}

Price, Emmett W. 1929. "Two new species of trematodes of the genus Parametorchis from fur-bearing animals." Proceedings of the United States National Museum 76(2809), 2-6. https://doi.org/10.5479/si.00963801.76-2809.1.

View This Item Online: $\underline{\text { https://www.biodiversitylibrary.org/item/88912 }}$

DOI: https://doi.org/10.5479/si.00963801.76-2809.1

Permalink: https://www.biodiversitylibrary.org/partpdf/78233

\section{Holding Institution}

Smithsonian Libraries

\section{Sponsored by}

Smithsonian

\section{Copyright \& Reuse}

Copyright Status: Public domain. The BHL considers that this work is no longer under copyright protection.

This document was created from content at the Biodiversity Heritage Library, the world's largest open access digital library for biodiversity literature and archives. Visit BHL at https://www.biodiversitylibrary.org. 